\title{
Project Risk Assessment in Enterprises with the Use of TOPSIS Method in the 2014-2020 Perspective
}

\author{
Ludmita Walaszczyk*
}

\begin{abstract}
Nowadays the homogeneous market with 500 billion consumers, 220 billion employees and 20 billion employers is the main instrument enabling the development of competitive and innovative Europe. One of the ways for companies to design innovative products is to participate in the execution of different projects. Each country offers many initiatives, mainly financed by the European Union (it is currently the 2014-2020 perspective). Thanks to participation in them, employers have the possibility to improve their business and develop products they need.

In order to achieve a product of a good quality, it must be managed correctly. There are a lot of methods which can be used in the project management process; however, the chosen methods should be clear and give proper results. One of the crucial aspects of the evaluation process is risk assessment as it enables one to find any abnormalities in the project.

Employers do not use any specialised tools enabling them to evaluate the risk during the project development. That is why many companies make products that are very difficult to sell on the market or even to use due to many defects. The risk can be evaluated with different methods, both qualitative and quantitative. The main objective of the article is to present the values for the company when using the semi-quantitative TOPSIS method (Hwang and Yoon, 1981) to measure risk in the projects executed in the 2014-2020 perspective. Therefore, the author indicates the advantages of TOPSIS method and presents how it can be used in practice.
\end{abstract}

Keywords: TOPSIS method, risk assessment, the 2014-2020 perspective, project management.

Submitted: 19.08.2016 | Accepted: 13.10.2016

\section{Zarządzanie ryzykiem projektu w przedsiębiorstwie w ramach perspektywy 2014-2020 z wykorzystaniem metody TOPSIS}

W obecnych czasach homogeniczny rynek obejmujący 500 milionów konsumentów, 220 milionów pracowników i 20 milionów pracodawców jest głównym instrumentem umożliwiajacym rozwój konkurencyjnej $i$ innowacyjnej Europy. Jednym ze sposobów uzyskania przez firmy innowacyjnych produktów jest uczestnictwo w realizacji różnego rodzaju projektów. Poszczególne kraje oferuja wiele inicjatyw, głównie finansowanych przez Unie Europejska (obecnie jest to perspektywa 2014-2020). Dzięki uczestnictwu w programach unijnych pracodawcy maja możliwość wzmocnienia pozycji swojego przedsiębiorstwa i opracowania produktów, na które jest zapotrzebowanie.

Ludmiła Walaszczyk - PhD, The Institute for Sustainable Technologies - National Research Institute. Mailing address: The Institute for Sustainable Technologies - National Research Institute, Pułaskiego St. 6/10, 26-600 Radom; e-mail: ludmila.walaszczyk@itee.radom.pl. Ministry of Science
and Higher Education Republic of Poland
The creation of the English-language version of these publications is financed in the framework of contract No. 768/P-DUN/2016 by the Ministry of Science and Higher Education committed to activities aimed at the promotion of education. 
W celu uzyskania produktów o wysokiej jakości, projekt musi być odpowiednio zarzqdzany. Istnieje wiele metod mogacych mieć zastosowanie w procesie zarzadzania projektem, jednak wybrane metody musza być jasne i odpowiednie do oceny danego rezultatu. Jednym z kluczowych aspektów procesu ewaluacji jest zarządzanie ryzykiem, jako że umożliwia ono wskazanie wszelkich odchyleń $w$ realizacji projektu.

Pracodawcy zazwyczaj nie stosuja narzędzi specjalistycznych w ewaluacji ryzyka $w$ trakcie realizacji projektu. Z tego też względu wiele firm wytwarza produkty, które później trudno sprzedać na rynku, bądź które obarczone sa wieloma wadami. Ryzyko może być oceniane $z$ wykorzystaniem wielu metod, zarówno jakościowych, jak i ilościowych. Gtównym celem artykułu jest przedstawienie semi-ilościowej metody TOPSIS (Hwang i Yoon, 1981) do pomiaru ryzyka w projektach realizowanych $w$ ramach perspektywy 2014-2020. Z tego względu autor wskazuje zalety metody TOPSIS i przedstawia, w jaki sposób może być ona wykorzystana w praktyce.

Słowa kluczowe: metoda TOPSIS, zarządzanie ryzykiem, perspektywa 2014-2020, zarządzanie projektem.

Nadesłany: 19.08.2016 | Zaakceptowany do druku: 13.10.2016

JEL: D81, O22

\section{Introduction}

A very important aspect of increasing the competitiveness of enterprises on the market is to know how to design and maintain project results to be in the interest of a large group of people. Projects have to be systematically evaluated and that is why it is necessary to develop efficient tools which would be quite easy to learn and use for enterprises and which would allow for a credible and detailed evaluation of the projects. In the literature (among others Jakobsen et al., 2002, pp. 22-25; Koponen et al., 2008, p. 2; PARP, 2010, pp. 14-16), there are methods for the assessment of projects and their results, but they are mostly qualitative and subjective such as interviews, expert panels or comparative analyses without any methodological approach (Łopacińska, 2011, p. 34).

The question is which methods should be used in the 2014-2020 perspective. This perspective offers a lot of possibilities for calls for proposals, both at the national and regional levels. In order to get funding and execute the project correctly afterwards, it is necessary to pay attention to many aspects which are inseparably linked with the project. In this article, the author focuses on risk. It must be considered not only during the project execution but also before the commencement of the project. Therefore, it is indispensable to know which method for risk measurement gives the best results and is quite simple to use.

\section{Literature Review on Methodologies and Methods for Project Management Including the Risk Aspect}

The author made a two-step literature review which concerned the risk aspect. Firstly, risk methodologies were analysed. Later on, the author paid attention to different methods which are usually used for risk assessment.

Having analysed the state of the art, the author found several methodologies for project management which include the risk aspect ${ }^{1}$. The most popular ones are presented in Table 1.

Apart from general project management methodologies, the author also identified the risk management methodologies which are aimed only at the risk aspect (Table 2).

Risk is assessed with the use of various methods. There are qualitative or quantitative methods which can be later on grouped in various ways, e.g. individual methods, MCDA methods or grouped methods. The most common ones are listed in Table 3.

The author pays a special attention to the MCDA methods, which are indispensable in the case of the necessity to select or rank various variants and take a decision. Therefore, in order to choose an appropriate method for risk assessment in a project in the 2014-2020 perspective, the author compared the multi-criteria decision methods taking into account the following cri- 
Table 1. Methodologies for project management including the risk aspect

\begin{tabular}{|l|l|}
\hline \multicolumn{2}{|c|}{ Methodology } \\
\hline $\begin{array}{l}\text { PRINCE 2 (Projects } \\
\text { in Controlled } \\
\text { Environments) }\end{array}$ & $\begin{array}{l}\text { PRINCE 2 methodology is aimed at results and not individual tasks. During } \\
\text { the project execution, the risk concerning individual activities is measured } \\
\text { (Kisielnicki, 2013, p. 314). }\end{array}$ \\
\hline PMBOK & $\begin{array}{l}\text { PMBOK® methodology presents the organisation of work in the form of } \\
\text { processes, which enables effective project management. The management } \\
\text { processes are divided into groups (initiation, planning, execution, } \\
\text { monitoring and steering and completion) and areas one of which concerns } \\
\text { risk management (Project Management Institute, 2013). }\end{array}$ \\
\hline $\begin{array}{l}\text { BS 6079-1: 2010 } \\
\text { British Standard }\end{array}$ & $\begin{array}{l}\text { BS 6079-1: 2010 methodology describes various ways of enterprise } \\
\text { organisation: functional organisation, matrix organisation and project- } \\
\text { driven organisation. Due to the fact that projects are tools for change } \\
\text { implementation in organisations, various ways of project execution are } \\
\text { described (BSI, 2010). }\end{array}$ \\
\hline $\begin{array}{l}\text { CMMISM } \\
\text { (Capability } \\
\text { Maturity Model } \\
\text { Integration) }\end{array}$ & $\begin{array}{l}\text { CMMISM methodology describes four groups of processes: project } \\
\text { management, process management, engineering and support. Project } \\
\text { management includes the following areas: project planning, project steering } \\
\text { and monitoring, contact with suppliers, integrated project management, risk } \\
\text { management and qualitative project management (CMMI, 2010). }\end{array}$ \\
\hline
\end{tabular}

Source: elaborated by the author.

Table 2. Risk management methodologies (Walaszczyk, 2016, pp. 35-36)

\begin{tabular}{|l|l|}
\hline \multicolumn{2}{|c|}{ Risk management methodology } \\
\hline $\begin{array}{l}\text { ISO/IEC 31010:2009 } \\
\text { - International } \\
\text { Organization for } \\
\text { Standardization }\end{array}$ & $\begin{array}{l}\text { The standard for risk management, especially risk assessment. The described } \\
\text { techniques of risk assessment support taking decisions by organisations and } \\
\text { help to understand how risk can influence the achievement of the results. } \\
\text { The necessity of systematic control of the initiative is also underlined (ISO/ } \\
\text { IEC 31010:2009, Risk Management - Risk Assessment Techniques). }\end{array}$ \\
\hline $\begin{array}{l}\text { ISO 31000 Risk } \\
\text { Management - } \\
\text { Principles and } \\
\text { Guidelines on } \\
\text { Implementation } \\
\text { - International } \\
\begin{array}{l}\text { Organization for } \\
\text { Standardization }\end{array}\end{array}$ & $\begin{array}{l}\text { ISO 31000 includes basic directions on risk management. The standard } \\
\text { can be used in various enterprises (private and public) for group or } \\
\text { individual tasks. The standard does not concern a specified sector or } \\
\text { industrial branch. It can be applied to various tasks, including strategies, } \\
\text { decisions, operations, projects, products or services (ISO 31000 Risk } \\
\text { Management - A Practical Guide for SMEs). }\end{array}$ \\
\hline $\begin{array}{l}\text { BS 31100: 2011 Code } \\
\text { of Practice for Risk } \\
\text { Management - British } \\
\text { Standard Institution }\end{array}$ & $\begin{array}{l}\text { The standard underlines the necessity of risk management for the } \\
\text { improvement of organisation management, with risk being identified } \\
\text { separately for different parts of the task. The standard indicates that the } \\
\text { risk management process should enable one to choose effective and effi- } \\
\text { cient ways thanks to which risk management can be performed at various } \\
\text { levels of the organisation. }\end{array}$ \\
\hline $\begin{array}{l}\text { A Risk Management } \\
\text { Standard - IRM/ } \\
\text { Alarm/AIRMIC 2002 } \\
\text { - The Institute of } \\
\text { Risk Management }\end{array}$ & $\begin{array}{l}\text { The standard includes the following sections: risk identification, risk } \\
\text { management, risk assessment, risk analysis, risk evaluation in order to } \\
\text { minimise or eliminate risk, monitoring of risk management (Institute of } \\
\text { Risk Management, A Risk Management Standard, 2002). }\end{array}$ \\
\hline
\end{tabular}

Wydział Zarządzania UW ～DOI 10.7172/1733-9758.2016.21.6 
Table 2 cont.

\begin{tabular}{|l|l|}
\hline $\begin{array}{l}\text { RAMP (Risk Analysis } \\
\text { and Management of } \\
\text { Projects) - Institution } \\
\text { of Civil Engineers } \\
\text { and the Institute and } \\
\text { Faculty of Actuaries }\end{array}$ & $\begin{array}{l}\text { In RAMP methodology, the risk analysis includes four stages: the launch } \\
\text { of RAMP procedures, risk identification, risk management, the final } \\
\text { phase. Phases 2 and 3 are especially important. In phase no 2, there } \\
\text { are risk identification and assessment and the use of adequate meth- } \\
\text { ods enabling risk minimisation or elimination. Phase no 3 includes risk } \\
\text { control and observation of changes which can occur (Institution of Civil } \\
\text { Engineers, 2014). }\end{array}$ \\
\hline $\begin{array}{l}\text { PRAM (Project } \\
\text { Risk Analysis and } \\
\text { Management) - The } \\
\text { Association of Project } \\
\text { Managers }\end{array}$ & $\begin{array}{l}\text { The methodology enables the risk analysis related to the project } \\
\text { and management of this risk. If the methodology is used correctly, } \\
\text { the probability of the project completion with success increases. } \\
\text { The methodology process contains two phases: risk analysis and risk } \\
\text { management (APM Risk Management Specific Interest Group, } \\
\text { 2010). }\end{array}$ \\
\hline $\begin{array}{l}\text { M_o_R (Management } \\
\text { of Risk) - British } \\
\text { Cabinet Office }\end{array}$ & $\begin{array}{l}\text { The methodology can be used at different levels of the organisation - } \\
\text { strategic, programme, project, operational. The aim of the methodology } \\
\text { is to identify the policy of risk management; relevant strategies and plans } \\
\text { for programmes and projects; systematic risk identification and analysis; } \\
\text { risk management (M_o_R } 2010 \text { - Management of Risk: Guidance for } \\
\text { Practitioners, 2010). }\end{array}$ \\
\hline $\begin{array}{l}\text { Risk Management } \\
\text { Methodology - } \\
\text { European Union } \\
\text { Agency for Network } \\
\text { and Information } \\
\text { Security }\end{array}$ & $\begin{array}{l}\text { This risk management methodology is possible to use in short-, mid- or } \\
\text { long-term perspectives. It aims at the definition of the scope and frames } \\
\text { of risk management, the risk assessment, the elimination or minimi- } \\
\text { sation of risk and the creation of staff awareness of the possibilities of } \\
\text { risk occurrence (European Union Agency for Network and Information } \\
\text { Security, 2016). }\end{array}$ \\
\hline
\end{tabular}

Source: elaborated by the author.

Table 3. Methods used in risk assessment

\begin{tabular}{|l|l|}
\hline \multicolumn{2}{|c|}{ Method } \\
\hline $\begin{array}{l}\text { Qualitative } \\
\text { methods }\end{array}$ & $\begin{array}{l}\text { Brainstorming (Wilson, 2013), Comparative Analysis (Innovation Portal, } \\
\text { 2016), Risk Scenarios (Ziarkowski, 2004, p. 24), Expert Panel (Ziglio, 1996), } \\
\text { Risk Mapping (Ministry of Finance, 2004), Decision Tree Method (Albright } \\
\text { et al., 2010), Failure Mode and Effects Analysis (Solinski, 2016), Fault Tree } \\
\text { Analysis (Wardziński, 1996, p. 22). }\end{array}$ \\
\hline $\begin{array}{l}\text { Quantitative } \\
\text { methods }\end{array}$ & $\begin{array}{l}\text { Probability \& Statistical Methods, PERT Method (Hulett, 2009, p. 208), VaR } \\
\text { Method (Juselius, 2006). }\end{array}$ \\
\hline $\begin{array}{l}\text { Semi-quantitative } \\
\text { methods }\end{array}$ & $\begin{array}{l}\text { Multi-Attribute Utility Theory - MAUT (Becker, 2011, pp. 21-36), Multiple- } \\
\text { Criteria Decision Analysis - MCDA (Greco, 2016), Comparative Risk } \\
\text { Assessment Method (Schutz, 2006). }\end{array}$ \\
\hline $\begin{array}{l}\text { MCDA methods } \\
\text { (included here as } \\
\text { important for the } \\
\text { risk aspect) }\end{array}$ & $\begin{array}{l}\text { ELECTRE - Elimination and Choice Expressing Reality (Govindan et } \\
\text { al., 2016), PROMETHEE - Preference Ranking Organization Method for } \\
\text { Enrichment of Evaluations (Corrente et al., 2013), TOPSIS - Technique for } \\
\text { Order Preference by Similarity to an Ideal Solution (Hwang et al., 1981), } \\
\text { AHP - Analytic Hierarchy Process (Saaty, 2001), Entropy method (Beruvides } \\
\text { et al., 2016) and fuzzy logic (de Salles et al., 2016). }\end{array}$ \\
\hline
\end{tabular}

Source: elaborated by the author. 
teria (Santana, 1996; Zanatis et al., 1998; Triantaphyllou, 2010):

- normalisation;

- weights;

- time-consumption

- algorithm extension.

The analysis proved that in the case of many methods (ELECTRE, TOPSIS, entropy method, fuzzy logic), normalisation of input data is a must. This step is not required in the case of the AHP method. On the other hand, if attention is paid to the aspect of time-consumption, it is adequate for the AHP and ELECTRE methods. Time-consumption is not characteristic for TOPSIS, entropy and fuzzy logic methods. Considering the algorithm, it is not extended in relation to the TOPSIS method. In the remaining methods the algorithm is extended, except for the ELECTRE method. With regard to the criterion of weighting, the weights are characteristic for all analysed methods. Having performed a comparative analysis of multicriteria decision methods (Łopacińska, 2014), the author stated the following advantages of the TOPSIS method:

- risk assessment unlimited by the number of measurement criteria;

- time-consumption is relatively low;

- the level of clarity of results is high;

- as it is a mathematical method, it enables numerical presentation of the results (Książek, 2011).

Being a mathematical method, the TOPSIS may seem to be complex and complicated, but actually it employs an Excel spreadsheet and a formula that can be designed quickly.

Moreover, the TOPSIS method has become more common (Behzadian et al. 2012). Growing interest in this method is confirmed by the steady increase in publications, e.g. in 2000 there were only 5 publications on the TOPSIS method, while in 2010 - 130. However, the method is not popular in the European countries (it is most frequently used in the United Kingdom), but it is very popular in the Asian countries (Taiwan, China, Iran, Turkey).

\section{Research Methodology}

The main objective of the article is to present the value for the company when using the semi-quantitative TOPSIS method to measure risk in the projects executed in the 2014-2020 perspective. The author held interviews in order to state which elements should be taken into account while managing the project risk in a company with a special attention to the 2014-2020 perspective. Later on, the author shows how to use the TOPSIS method with the selected elements and what results can be expected after using this method.

The author held direct and CATI (Computer Assisted Telephone Interview) interviews with entrepreneurs from different regions in Poland, mainly from the Masovian region. Among 150 entrepreneurs, 105 agreed to participate in the research.

In order to fulfil the main objective, the following issues were considered:

- the proposition of the criteria which should be used during risk assessment;

- the correlation of the selected criteria for the TOPSIS method;

- the indication of criteria which are under risk.

\section{Criteria Necessary to be Considered in the Risk Assessment Process in the 2014-2020 Perspective}

When managing the project, the entrepreneur must take into account formal and content-related aspects. Again, taking into account the 2014-2020 financial perspective, formal aspects are usually laid down in the documents concerning the individual programme or initiative. They can be the following: the submission of the project to the right institution; the submission of the project at the right time; the preparation of the project proposal according to the instruction; the necessity of being registered as the entrepreneur; the project is executed in the area of Poland; the project is systematically presented in the form of reports to the financing institution, etc.

The formal criteria are easy to supervise on condition that the entrepreneur systematically checks the requirements of the financing institution. In fact, most of formal criteria must be satisfied at the stage of the project submission.

The content-related aspects are most difficult to control. Therefore, the author gathered the criteria which seemed to be the most important for companies. Companies were given the evaluation elements 
which must be considered in the programmes financed by the National Centre for Research and Development, the Polish Agency for Enterprise Development and within Regional Operational Programmes.
The author gathered all content-related aspects based on the documentation of calls.

Table 4 includes the criteria which are crucial for entrepreneurs in the 2014-2020 perspective as they are the most problematic

Table 4. Evaluation criteria which are selected by entrepreneurs as the most important in the 2014-2020 financial perspective

\begin{tabular}{|c|c|}
\hline Criterion & Description \\
\hline $\begin{array}{l}\text { Project includes both indus- } \\
\text { trial and experimental } \\
\text { research }\end{array}$ & $\begin{array}{l}\text { The project includes two types of research: industrial and } \\
\text { experimental. It is underlined that the project without experimental } \\
\text { research does not get funds. }\end{array}$ \\
\hline $\begin{array}{l}\text { Diffusion effects of the R\&D } \\
\text { activity }\end{array}$ & $\begin{array}{l}\text { The diffusion effect must be only fulfilled by big enterprises. They } \\
\text { must plan the cooperation with SMEs or research organisations } \\
\text { during the project execution or during } 3 \text { years after its completion. }\end{array}$ \\
\hline $\begin{array}{l}\text { Project compliance with } \\
\text { smart specialisation }\end{array}$ & $\begin{array}{l}\text { The main product of the project must be relevant to smart } \\
\text { specialisation. }\end{array}$ \\
\hline $\begin{array}{l}\text { Development of product or } \\
\text { process innovation }\end{array}$ & $\begin{array}{l}\text { The aim of the project is to develop either product innovation or } \\
\text { process innovation. Other kinds of innovations (marketing and } \\
\text { organisational) are not acceptable. }\end{array}$ \\
\hline $\begin{array}{l}\text { Implementation of project } \\
\text { results in business activity of } \\
\text { the entrepreneur }\end{array}$ & $\begin{array}{l}\text { The enterprises which implement results of industrial or } \\
\text { experimental research are promoted. The implementation must } \\
\text { take place within } 3 \text { years since the project was completed. } \\
\text { Within partnership projects, the implementation can take place in } \\
\text { the enterprise or in a partner institution that is not a research unit. }\end{array}$ \\
\hline $\begin{array}{l}\text { Cooperation with R\&D insti- } \\
\text { tution }\end{array}$ & $\begin{array}{l}\text { The 2014-2020 perspective promotes the cooperation of "science- } \\
\text { industry" type. }\end{array}$ \\
\hline $\begin{array}{l}\text { Participation of the applicant } \\
\text { in a key cluster }\end{array}$ & $\begin{array}{l}\text { The project should be executed by the company or the consortium } \\
\text { included in a key cluster. }\end{array}$ \\
\hline $\begin{array}{l}\text { Necessity to invest more } \\
\text { equity }\end{array}$ & $\begin{array}{l}\text { Projects are promoted where the EU funding is decreased by the } \\
\text { inclusion of more equity of the entrepreneur (mainly in regional } \\
\text { initiatives). }\end{array}$ \\
\hline $\begin{array}{l}\text { Identification of possible } \\
\text { risks }\end{array}$ & $\begin{array}{l}\text { The risks should be specified at the following stages: } \\
\text { - the research execution; } \\
\text { - the implementation of new or modified products or technologies } \\
\text { in the market. }\end{array}$ \\
\hline $\begin{array}{l}\text { Development of the out- } \\
\text { comes needed on the market }\end{array}$ & $\begin{array}{l}\text { Two criteria are assessed: market needs and profitability of the } \\
\text { implementation. }\end{array}$ \\
\hline $\begin{array}{l}\text { Originality of the } \mathrm{R} \& \mathrm{D} \\
\text { results }\end{array}$ & $\begin{array}{l}\text { Originality is assessed with the following approach taken into } \\
\text { account: the product which is new on the market; the product } \\
\text { which is new in the world; the emerging innovation. }\end{array}$ \\
\hline Transregional character & $\begin{array}{l}\text { Projects of transnational character are promoted. The project } \\
\text { should be executed in a consortium with at least one organisation } \\
\text { from another region or the project should be executed in the area } \\
\text { of more than one region. }\end{array}$ \\
\hline
\end{tabular}

Source: elaborated by the author based on the documents of calls for proposals from the National Centre for Research and Development (NCBiR) and Regional Operational Programmes. 
(the difficulty with understanding or the lack of information on how to fulfil them).

The criteria mentioned above are known already at the ex-ante stage, when submitting the project proposal. However, in order for the project to be successfully completed, the executors should have these criteria in mind all the time and assess them regularly in relation to each task during the whole execution process of the project.

\section{TOPSIS Method for Risk}

\section{Assessment}

In order to check which of the criteria is fulfilled at the highest or lowest level, it is necessary to make comparisons. The author proposed to use the TOPSIS method, which is quite easy to use and which enables the identification of the most and least promising criteria. The steps are as follows:

1. Assignment of the values to each criterion - here the executors can assume that the criteria $(\mathrm{K})^{2}$ which are the most difficult to fulfil are the most important. The values were assigned to each criterion with the use of the AHP method. The criteria are assessed in relation to each project task $(\mathrm{T})^{3}$. The values are given by the team which is responsible for the project.

\begin{tabular}{|c|c|c|c|c|c|c|c|}
\hline \multirow{3}{*}{ Ti } & \multicolumn{7}{|c|}{ Criteria (K) / weights } \\
\cline { 2 - 8 } & K1 & K2 & K3 & K4 & K5 & K6 & K7 \\
\cline { 2 - 8 } & $\mathbf{0 . 1 8 0}$ & $\mathbf{0 . 0 6 5}$ & $\mathbf{0 . 3 4 0}$ & $\mathbf{0 . 1 1 8}$ & $\mathbf{0 . 1 7 3}$ & $\mathbf{0 . 0 7 4}$ & $\mathbf{0 . 0 4 9}$ \\
\hline $\mathrm{T} 1$ & 10 & 20 & 10 & 15 & 10 & 10 & 10 \\
\hline $\mathrm{T} 2$ & 15 & 15 & 30 & 35 & 10 & 20 & 10 \\
\hline $\mathrm{T} 3$ & 10 & 30 & 25 & 40 & 20 & 10 & 10 \\
\hline $\mathrm{T} 4$ & 15 & 20 & 40 & 25 & 15 & 15 & 15 \\
\hline
\end{tabular}

2. Normalisation of values assigned in point 1

$$
n_{i j}=\frac{x_{i j}}{\sqrt{\sum_{j=1}^{n} T_{i j}^{2}}}
$$

\begin{tabular}{|c|c|c|c|c|c|c|c|}
\hline & \multicolumn{7}{|c|}{ Criteria (K) / weights } \\
\cline { 2 - 8 } Ti & K1 & K2 & K3 & K4 & K5 & K6 & K7 \\
\cline { 2 - 8 } & $\mathbf{0 . 1 8 0}$ & $\mathbf{0 . 0 6 5}$ & $\mathbf{0 . 3 4 0}$ & $\mathbf{0 . 1 1 8}$ & $\mathbf{0 . 1 7 3}$ & $\mathbf{0 . 0 7 4}$ & $\mathbf{0 . 0 4 9}$ \\
\hline T1 & 0.0706 & 0.0296 & 0.0599 & 0.0292 & 0.0602 & 0.0258 & 0.0214 \\
\hline T2 & 0.1059 & 0.0222 & 0.1796 & 0.0681 & 0.0602 & 0.0515 & 0.0214 \\
\hline T3 & 0.0706 & 0.0444 & 0.1497 & 0.0779 & 0.1205 & 0.0258 & 0.0214 \\
\hline T4 & 0.1059 & 0.0296 & 0.2395 & 0.0487 & 0.0903 & 0.0386 & 0.0321 \\
\hline
\end{tabular}

3. Determination of the worst alternative $\left(\mathrm{T}^{-}\right)$and the best alternative $\left(\mathrm{T}^{+}\right)$

$$
\begin{aligned}
T^{+} & =\left\{v_{1}^{+}, v_{2}^{+}, \ldots, v_{n}^{+},\right\}= \\
& =\left\{\left(\max _{i} v_{i j} \mid j \in K_{b}\right),\left(\min _{i} v_{i j} \mid j \in K_{c}\right)\right\} \\
T^{+} & =\left\{v_{1}^{+}, v_{2}^{+}, \ldots, v_{n}^{+}\right\}= \\
& =\left\{\left(\max _{i} v_{i j} \mid j \in K_{b}\right),\left(\min _{i} v_{i j} \mid j \in K_{c}\right)\right\}
\end{aligned}
$$

where:

$\mathrm{K}_{\mathrm{b}}$ - a set of criteria having a positive impact - benefits,

$\mathrm{K}_{\mathrm{c}}$ - a set of criteria having a negative impact - limits, costs.

\begin{tabular}{|l|l|l|l|l|l|l|l|}
\hline $\mathbf{T}+$ & 0.0706 & 0.0222 & 0.0599 & 0.0292 & 0.0602 & 0.0258 & 0.0214 \\
\hline $\mathbf{T}-$ & 0.1059 & 0.0444 & 0.2395 & 0.0779 & 0.1205 & 0.0515 & 0.0321 \\
\hline
\end{tabular}

\begin{tabular}{l|l|l|l|l|l|l|l|}
\hline T- & 0.1059 & 0.0444 & 0.2395 & 0.0779 & 0.1205 & 0.0515 & 0.0321 \\
\hline
\end{tabular}

4. Calculation of the distance between the target alternative $i$ and the best condition $\left(\mathrm{D}^{+}\right)$

$$
D_{i}^{+}=\sqrt{\sum_{i=1}^{n}\left(v_{i j}-v_{j}^{+}\right)^{2}}
$$

\begin{tabular}{|c|c|c|c|c|c|c|c|}
\hline \multicolumn{7}{|c}{ Criteria (K) / weights } \\
\cline { 2 - 8 } T1 & K1 & K2 & K3 & K4 & K5 & K6 & K7 \\
\cline { 2 - 8 } & $\mathbf{0 . 1 8 0}$ & $\mathbf{0 . 0 6 5}$ & $\mathbf{0 . 3 4 0}$ & $\mathbf{0 . 1 1 8}$ & $\mathbf{0 . 1 7 3}$ & $\mathbf{0 . 0 7 4}$ & $\mathbf{0 . 0 4 9}$ \\
\hline T1 & 0.0000 & 0.0074 & 0.0000 & 0.0000 & 0.0000 & 0.0000 & 0.0000 \\
\hline T2 & 0.0353 & 0.0000 & 0.1197 & 0.0389 & 0.0000 & 0.0258 & 0.0000 \\
\hline T3 & 0.0000 & 0.0222 & 0.0898 & 0.0487 & 0.0602 & 0.0000 & 0.0000 \\
\hline T4 & 0.0353 & 0.0074 & 0.1796 & 0.0195 & 0.0301 & 0.0129 & 0.0107 \\
\hline
\end{tabular}

5. Calculation of the distance between the target alternative $i$ and the worst condition $\left(\mathrm{D}^{-}\right)$

$$
D_{i}^{-}=\sqrt{\sum_{i=1}^{n}\left(v_{i j}-v_{j}^{-}\right)^{2}}
$$

\begin{tabular}{|c|c|c|c|c|c|c|c|}
\hline \multirow{2}{*}{ Ti } & \multicolumn{7}{|c|}{ Criteria (K) / weights } \\
\cline { 2 - 8 } & K1 & K2 & K3 & K4 & K5 & K6 & K7 \\
\cline { 2 - 7 } & $\mathbf{0 . 1 8 0}$ & $\mathbf{0 . 0 6 5}$ & $\mathbf{0 . 3 4 0}$ & $\mathbf{0 . 1 1 8}$ & $\mathbf{0 . 1 7 3}$ & $\mathbf{0 . 0 7 4}$ & $\mathbf{0 . 0 4 9}$ \\
\hline T1 & -0.0353 & -0.0148 & -0.1796 & -0.0487 & -0.0602 & -0.0258 & -0.0107 \\
\hline T2 & 0.0000 & -0.0222 & -0.0599 & -0.0097 & -0.0602 & 0.0000 & -0.0107 \\
\hline T3 & -0.0353 & 0.0000 & -0.0898 & 0.0000 & 0.0000 & -0.0258 & -0.0107 \\
\hline T4 & 0.0000 & -0.0148 & 0.0000 & -0.0292 & -0.0301 & -0.0129 & 0.0000 \\
\hline
\end{tabular}


6. Calculation of the relative closeness to the ideal solution $\left(\mathrm{C}^{+}\right)$

$$
C_{i}^{+}=\frac{D_{i}^{-}}{D_{i}^{-}+D_{i}^{-}}, \quad C_{i}^{+} \in\langle 0,1\rangle
$$

\begin{tabular}{|c|c|c|c|}
\cline { 2 - 4 } \multicolumn{1}{c|}{} & $\mathbf{D}^{+}$ & $\mathbf{D}^{-}$ & $\mathbf{C}^{+}$ \\
\hline $\mathrm{T} 1$ & 0.0074 & 0.1993 & 0.9642 \\
\hline $\mathrm{T} 2$ & 0.1333 & 0.0890 & 0.4003 \\
\hline $\mathrm{T} 3$ & 0.1206 & 0.1004 & 0.4543 \\
\hline T4 & 0.1874 & 0.0463 & 0.1981 \\
\hline
\end{tabular}

The calculations made above enabled the indication of the strongest and the weakest tasks in the project, taking into account the accepted criteria. It turned out that task no. 1 was characterised by the lowest, and task no. 4 by the highest risk level in the given example. In such a situation, it is necessary for the organisation executing the project to decide if it is reasonable to continue task no. 4 . The risk is high, so the best solution seems to be to stop the task, but if it is not possible, it is necessary to introduce significant changes in order to complete the project as planned.

\section{Conclusions}

Risk is a very important element of management in the company. It is not an easy task, because usually methodologies do not specify criteria which should be taken into consideration. In the article, the author proposed to use the TOPSIS method for risk assessment during project management in order to verify which tasks are correctly fulfilled and which of them should be corrected. The author considered the criteria which are obligatory in the 2014-2020 financial perspective in most initiatives. This proposition is a supporting tool for systematic risk management in the project as an easy and user-friendly method.

\section{Footnotes}

1 In order to assess risk in the project, it is necessary to see two different perspectives: the product perspective and the project perspective as a whole. The product risk is described in detail by the author in another publication (Walaszczyk, 2016, pp. 34-43). This article concerns only the project aspects.

2 The entrepreneurs chose the following aspects to be compared with the TOPSIS method:
Development of product or process innovation (K1); Diffusion effects of the R\&D activity (K2); Development of the outcomes needed on the market (K3); Identification of possible risks (K4); Project includes both industrial and experimental research (K5); Cooperation with R\&D institution (K6); Implementation of project results in business activity of the entrepreneur (K7).

3 The tasks concern the development of product evaluation methods: T1 - Development of the technological readiness evaluation method; T2 - Development of the commercial potential evaluation method; T3 - Development of the implementation risk evaluation method; T4 Development of the innovativeness assessment method.

\section{References}

Albright, S.C., Wayne, W. and Zappe, Ch. (2014). Data analysis and decision making, $4^{\text {th }}$ edition. South Western Cengage Learning.

APM Risk Management Specific Interest Group (2010). Project Risk Analysis and Management Guide, $2^{\text {nd }}$ edition.

Becker, J. (2011). Analiza funkcjonalna metod ilościowych na potrzeby systemu wspomagania decyzji (part I). Metody ilościowe w badaniach ekonomicznych, 12/2.

Behzadian, M., Otaghsara, S.K., Yazdani, M. and Ignatius, J. (2012). A State-of the-Art Survey of TOPSIS Applications. Expert Systems with Applications, 39. Elsevier.

Beruvides, G., Quiza, R. and Haber, R.E. (2016). Multi-objective optimization based on an improved cross-entropy method. A case study of a microscale manufacturing process. Information Sciences, 334-335.

BSI (2010). BS 6079-1:2010. Project management. Principles and guidelines for the management of projects.

Cebrowska, T. (2010). Rachunkowowść finansowa i podatkowa. Warszawa: Wydawnictwo Naukowe PWN.

Corrente, S., Greco, S. and Słowiński, R. (2013). Multiple Criteria Hierarchy Process with ELECTRE and PROMETHEE. Omega, 41(5), 820-846.

Churchil, N.C. and Levis, V.L. (1983). The five stages of small business growth. Harvard Business Review, May-June.

De Salles, D.C., Celestino, A., Neto, G. and Marujo, L. (2016). Using fuzzy logic to implement decision policies in system dynamics models. Journal Expert Systems with Applications, 55(C).

European Union Agency for Network and Information Security https://www.enisa.europa.eu/activities/ risk-management/current-risk/risk-managementinventory/rm-process (03.07.2016). 
Govindan, M.E. and Jepsen, K. (2016). ELECTRE: A comprehensive literature review on methodologies and applications. European Journal of Operational Research, 200(1), 198-215.

Greco, S. (ed.) (2016). Multiple Criteria Decision Analysis: State of the Art Surveys. Internationa Series in Operations Research \& Management Science, Vol. 78.

Hulett, D. (2009). Practical schedule risk analysis. Gower Publishing Company.

Hwang, C.L. and Yoon, K. (1981). Multiple Attribute Decision Making: Methods and Applications. Berlin: Springer-Verlag.

Institute of Risk Management (2002). A risk mana gement standard.

Institution of Civil Engineers (2014). Risk Analysis and Management for Projects (RAMP), $3^{\text {rd }}$ edition.

International Organization for Standardization (2015). ISO 31000 Risk management - a practical guide for $S M E S$.

International Organization for Standardization (2016). ISO/IEC 31010:2009, Risk management Risk assessment techniques.

Jakobsen, L. (ed.) (2002). Evaluation of the Programme for Interdisciplinary Materials Research Consortia. Oxford Research.

Juselius, K. (2006). The co-integrated VaR model: methodology and applications. Oxford University Press.

Kisielnicki, J. (2013). Zarzadzanie projektami badawczo-rozwojowymi. Warsaw: Oficyna Wolters Kluwer Business.

Koponen, P., Kalander, J.K. and Kuursisto, M (2008). FinNano Programme. Intermediate Evaluation. Helsinki: TEKES.

Książek, M. (2011). Analiza porównawcza wybranych metod wielokryterialnych oceny przedsiewzieć inwestycyjnych. Civil and Environmental Engineering, 2.

Łopacińska, L. (2011). Ponadstandardowe metody ewaluacji strategicznych programów badawczych. Problemy Eksploatacji, 3.

Łopacińska, L. (2014). Ewaluacja metodą TOPSIS projektów ERASMUS+. Edukacja Ustawiczna Dorostych, 2(85).

British Cabinet Office (2010). M o R® 2010 Management of Risk: Guidance for Practitioners.

Ministerstwo Finansów (Ministry of Finance) (2004). Zarzadzanie ryzykiem $w$ sektorze publicznym. Podręcznik wdrożenia systemu zarzadzania ryzykiem $w$ administracji publicznej $w$ Polsce.

Polish Agency for Enterprise Development (2010). Ocena efektywności i skuteczności programu bon na innowacje. Warsaw.
Portal Innowacji (Innovation Portal). Zarzadzanie ryzykiem $w$ projektach innowacyjnych. Retrieved from: http://www.pi.gov.pl/PARP/chapter_86197. asp?soid=0CA59D0084174201BA6A9E770D6BE 5AB (03.03.2016).

Project Management Institute (2013). A Guide to the Project Management Body of Knowledge (PMBOK Guide), $5^{\text {th }}$ edition.

Saaty, T.L. (1994). Highlights and critical points in the theory and application of the Analytic Hierarchy Process. European Journal of Operational Research, 74(3)

Santana, E.A. (1996). Múltiplos critérios: uma alternativa, apesar das fragilidades das soluções. 2nd International Congress of Industrial Engineering.

Schutz, H. (ed.) (2006). Comparative Risk Assessment: Concepts, Problems and Applications. Wiley $-\mathrm{VCH}$.

Soliński, B., Metody zarządzania jakościa FMEA. Analiza przyczyn wadliwości i krytyczności wad. Akademia Górniczo-Hutnicza, Wydział Zarządzania, Katedra Zarządzania Przedsiębiorstwem. Retrieved from: http://www.zarz.agh.edu.pl/bsolinsk/FMEA. html (03.03.2016).

Thlon, M. (2013). Charakterystyka i klasyfikacja ryzyka w działalności gospodarczej. Zeszyty Naukowe UEK, 902.

Triantaphyllou, E. (2010). Multi-Criteria Decision Making Methods: A Comparative Study. Springer US.

Walaszczyk, L. (2016). Metodyka zarządzania ryzykiem wdrożeniowym innowacyjnych produktów technicznych. E-mentor, 2(64), 34-43, http://dx.doi. org/10.15219/em64.1237.

Wardziński, A. (1996). Analiza drzew błędów systemów komputerowych zwiazanych $z$ bezpieczeństwem. Doctoral thesis, Politechnika Gdańska, Wydział Elektroniki, Telekomunikacji i Informatyki, Gdańsk.

Wawrzynek, J. (2007). Metody opisu i wnioskowania statystycznego. Akademia Ekonomiczna im. Oskara Langego we Wrocławiu.

Wilson, C. (2013). Brainstorming and beyond. A user-centered design method. Elsevier.

Zanakis, S.H., Solomon, A., Wishart, N. and Dublish, S. (1998). Multi-Attribute Decision Making: A Simulation Comparison of Select Methods. European Journal of Operational Research, 107.

Ziarkowski, R. (2004). Opcje rzeczowe oraz ich zastosowanie $w$ formutowaniu $i$ ocenie projektów inwestycyjnych. Katowice: WAE.

Ziglio, E. (1996). Gazing into the oracle: the Delphi method and its application to social policy and public health. London: Jessica Kingsley Publishers Ltd. 